DOI http://dx.doi.org/10.18551/rjoas.2016-01.01

\title{
THE ECONOMIC IMPACT OF MINIMART ON TRADITIONAL SHOP IN MALANG, EAST JAVA, INDONESIA
}

\author{
Bayu Adi Kusuma \\ University of Brawijaya, Indonesia \\ E-mail: bayu.fpub@ub.ac.id \\ Sirirat Kiatpathomchai \\ Prince of Songkla University, Thailand \\ E-mail: sirirat.k@psu.ac.th \\ Nuhfil Hanani AR. \\ University of Brawijaya, Indonesia \\ E-mail: nuhfil.fp@ub.ac.id
}

\begin{abstract}
Minimart is a modern store similar to convenience store. In urban areas in Indonesia, it is hard to find a location without a minimart. The proliferation of minimart in urban areas feared would displace the traditional shop. The study aims to measure the economic impact of the minimart on the traditional shop in Malang. 172 traditional shops scattered in Malang was purposively chosen in this study; 86 shops located near to the minimart, and 86 shops located away from the minimart. Using difference-in-difference estimation, the simple model reveals that the drop in revenue $(-125,116.28$ IDR) was not significant; on the other hands, the drop in profit $(-25,193.02$ IDR) was significant. The econometric model shows that the minimart gives the negative impact on both revenue $(-2.7 \%)$ and profit $(5.5 \%)$. However, the impact was not significant. Furthermore, the interview reveals that the declining in revenue and profit was caused by the loss in the number of buyers. The decline in revenue and profit has happened due to many emerging new traditional shop. The new traditional shops come up with several innovations to attract the buyers. The presence of the new traditional shop has forced the existing traditional shops to take action to survive. The four actions that most traditional shops did were: diversify products, better display, adding new brands and lower the prices.
\end{abstract}

\section{KEY WORDS}

Convenience store, minimarket, traditional retailer, East Java, difference-in-difference.

People cannot separate themselves from retail activities. Retailing gives impact on people lives. The retail business sector gives a substantial contribution to Gross Domestic Product (GDP). Retail business is a direct sale of goods in an outlet such as; kiosk, stall, traditional and modern market, department store, and boutique. It includes delivery services, which supply consumers for personal consumption.

Early 1970s was the beginning of massive changes in retail businesses of western countries. Retail market started changing in the west and east part of the world, America (Weitz \& Whitfield, 2010), Europe (Dawson, 2010), Africa, and Asia (Reardon, et.al, 2004). The 20th century was a decade of change for grocery retailing in Asia. More than ten years, throughout Asia, the rapid changes in the retail grocery business were recorded, driven by the retailer's investment in the establishment of new stores. The modern market growth rate in developing countries become a topic of interest because of its impact on agriculture, business, other retailers, welfare and nutrition (Traill, 2006).

Indonesia is the second fastest developing market in South-East Asia (Dyck, et.al, 2012). Retailing is one of the strategic businesses in Indonesia. It absorbs approximately 18.9 million people; it is the second largest sector in employment. In GDP, this sector is in the third position (13.8\%) after manufacturing (24.3\%), and agriculture (14.7\%). In contrast, 
Statistic Indonesia in 2013 reported that retail sector in East Java contribute $28.3 \%$, which is higher than West Java (14.1\%) and Jakarta (19.1\%).

The modern market and traditional markets in Indonesia are both experiencing growth (Dyck, et.al, 2012). An increase in traditional stores is not comparable to the increase in modern stores; the number of traditional stores has increased, but sales are decreasing. During 2004 - 2009, a very drastic increased occurred in the number of the minimart, the increased reached $600 \%$. The rapid growth of modern retail especially minimart raises concerns in the traditional retailer. The more proliferation of minimart should be wary of going to interrupt the traditional shop.

According to Malang Statistic, Malang is the second largest city in East Java, which often becomes a reference in regional economic development in East Java. The number of a minimart in Malang is growing rapidly, from only two outlets in 2006 to 144 outlets in 2011. There are three prominent brands of the minimart in Malang; Indomaret, Alfamart, and Alfamidi. If there is an Indomaret, then there can be found Alfamart nearby, and then there will also establish Alfamidi. Competition between Indomaret and Alfamart is a competition among modern retail business that is very dominant. In some places, one Indomaret is flanked by two Alfamart, and vice versa in other locations. It is hard to find a place without Indomaret or Alfamart within a radius of 500 meters. Traditional shops are the most affected. The impact of minimart seems to have been strongly felt by the traditional shop owners. Many shops are becoming increasingly deserted.

The study aims to measure the economic impact of the minimart on the traditional shop in Malang. The benefit of this study is to present information that is useful for the traditional shop to survive in the tight retail business competition.

\section{METHODOLOGY}

The study conducted in Malang, East Java, Indonesia. The population of the study is the traditional shop. In developing country, it is hard to determine the actual number of the traditional shop. Using Cochran (1977) with $7.5 \%$ of error, the total samples are 172 shops. The sample was purposively chosen based on the distance from the minimart; near and away, the year when the shop was opened; before 2006, and the shop size; at least $15 \mathrm{~m}^{2}$. Traditional shops that categorize 'near' were the traditional shop located less than $500 \mathrm{~m}$ from the minimart; while the traditional shops in 'away' category located at least $500 \mathrm{~m}$ from the minimart. There are 86 shops were near to minimart, and 86 shops are away from minimart. The existence of retail stores such as traditional store and minimart aims to satisfy the daily needs of the communities around the stores. Minimart with an average size of $200 \mathrm{~m}^{2}$ has an effective range of radius less than $500 \mathrm{~m}$; while the traditional shops with a smaller size than the minimart have an effective range narrower than the minimart. Joseph, et.al, (2008) adapted to determine the distance. This consideration is required to determine whether the minimart gives an impact on the performance of the traditional store. The two group of the sample should be similar in term of characteristics.

Data were collected using a structured questionnaire. To minimize the bias of data as a result of a subjective opinion of the respondent to the minimart; the purpose of the research did not inform to the respondent. Data in the period before the minimart established was the 2006 data. It was the data from digging up information based on records and memories of the traditional shop owners in 2006. This study assumed that the respondents still have a record and memory of the shop condition at the time before minimart established.

The difference-in-difference (DiD) estimation was used to measure the impact of the minimart on the traditional shop. DiD has been widely used to evaluate government policies and government programs (Pitt and Khandker, 1998; Binswange and Khandker, 1993; Duflo, 2001; Ravallion et.al, 1995; Jacoby, 2002; van de Walle 2004; ITPS, 2004; Galiani et.al, 2005). DiD was also used in the evaluation of health policies (Frankenberg, et.al, 2005; Thomas et al., 2003). In the study of the impact of modern retail on traditional retailers, it was used by Suryadarma et al., (2007, 2009); and Poesoro, (2008). Two DiD estimation models were used to estimate the minimart impact on the traditional shop performance, the 'simple' 
DiD model and the 'econometrics' DiD model. DID requires the recording of circumstances in two time periods (before and after) and in two groups of the sample (near and away) (Abadie, 2005; Ravallion, 2008). The simple DiD model was used to measure the changes in performance (revenue and profit) before and after minimart established. The simple DiD model are as follows:

$$
\text { Impact }=(\mathrm{T} 2-\mathrm{T} 1)-(\mathrm{C} 2-\mathrm{C} 1)
$$

Where T2: near minimart in 2011; T1: near minimart in 2006; C2: away from minimart in 2011; C1: away from minimart in 2006.

Paired sample t-test in each group of the sample was used to test the different performance before and after minimart established. Independent sample t-test in each periods of time was used to verify the difference performance between the groups. One sample t-test was used to test the impact of minimart. If the "Impact" equal to zero, minimart have no impact; if the "Impact" not equal to zero, minimart have an impact.

The econometrics DiD model was used to measure the impact of minimart on traditional shop. There were two measurements in this model, log revenue and log profit. The econometrics DiD model are as follow:

$$
\begin{gathered}
Y_{i t}=\alpha+\beta T_{\text {NearMart }}+\gamma t_{2011}+\delta T_{\text {NearMart }} \cdot t_{2011}+\varepsilon_{i} \\
Y_{i t}=\alpha+\beta T_{\text {NearMart }}+\gamma t_{2011}+\delta T_{\text {NearMart }} \cdot t_{2011}+\tau X_{i t}+\varepsilon_{i}
\end{gathered}
$$

Where $Y_{i t}$ is the dependent variable, the traditional shop performance (log revenue and log profit) $i$ in period $t ; T_{\text {NearMart }}$ is a binary variable of group; $=1$ if traditional shop near to minimart; $=0$ if away; $t_{2011}$ is a binary variable of period; $=1$ indicating "after" minimart established; $=0$ indicating "before" minimart establish; $T_{\text {NearMart }} . t_{2011}$ is an interaction term between group and period, = 1 only in the traditional shop near to minimart in the "after" period; $X_{i}$ is a vector of observed characteristic as a control variable; store size, the number of workers, and working hour; $\alpha, \beta, \gamma, \delta$, and $\tau$ are the regression parameter, $\delta$ identifies the impact; $\varepsilon_{i}$ is an error term of the regression

To find out if other factors played a role in changing the traditional shop performance observed characteristics were added to Eq. (2) as control variables. The used of the control variables were to describe how the average impact of the minimart varies with the changes in observed characteristic (Abadie, 2005).

\section{RESULTS AND DISCUSSION}

The Characteristic of Traditional Shop. DiD estimation require that the characteristics of the groups of samples should be comparable; it is the requirement to avoid bias. Table 1 shows that male is own most of the traditional shops. It is in line with the following characteristics that indicate most of the shops are the main source of family income. The education level of most of the owners is Junior High School. Most of the owner age is $41-$ 50 years old. The average is 46.41 years old. As for experience in managing the shop, most of the owners have experienced $10-20$ years. The average is 16.75 years of experience. Table 1 show there is no significant difference in the characteristics of the shop owners.

Table 2 shows that the traditional shop in Malang initiated by owners, the rest opened by his parents and continued by their descendants. Most of the traditional shops have been established for $10-30$ years. The traditional shop operates $10-15$ hours per day. It is different with the minimart that operates fifteen hours per day. In some places, minimart is open twenty-four hours a day. The average size of the traditional shop in Malang is 42.34 $\mathrm{m} 2$. More than $80 \%$ of traditional shops do not have a storeroom. Due to the small size, the traditional shop does not require many workers; most of the traditional shops do not hire employees. The owner simply relies on family members to assist the operational of the store. Table 2 shows there is no significant difference in the characteristics of the shop. 
RJOAS, 1(49), January 2016

Table 1 - Characteristic of Traditional Shop Owners in 2011

\begin{tabular}{|c|c|c|c|}
\hline \multirow{2}{*}{ Item } & \multicolumn{2}{|l|}{ Sample Group } & \multirow{2}{*}{ All $(n=172)$} \\
\hline & $\operatorname{Near}(n=86)$ & Away $(n=86)$ & \\
\hline \multicolumn{4}{|l|}{ Gender (\%) } \\
\hline - Male & 65.12 & 63.95 & 64.53 \\
\hline - Female & 34.88 & 36.05 & 35.47 \\
\hline \multicolumn{4}{|l|}{ Source of family income (\%) } \\
\hline - Trader & 80.23 & 62.78 & 71.51 \\
\hline - Self-employee & 8.14 & 10.47 & 9.30 \\
\hline - Government employee & 3.49 & 13.95 & 8.72 \\
\hline - Private employee & 4.65 & 6.98 & 5.81 \\
\hline - Unskilled labor & 3.49 & 5.81 & 4.65 \\
\hline \multicolumn{4}{|l|}{ Education level } \\
\hline - Elementary School & 39.53 & 17.44 & 28.49 \\
\hline - Junior High School & 32.56 & 43.02 & 37.79 \\
\hline - Senior High School & 20.93 & 29.07 & 25.00 \\
\hline - Under Graduate & 6.98 & 10.47 & 8.72 \\
\hline \multicolumn{4}{|l|}{ Age (years) } \\
\hline$-\quad<31$ & 8.14 & 1.16 & 4.65 \\
\hline$-31-40$ & 25.58 & 30.23 & 27.91 \\
\hline$-41-50$ & 26.74 & 47.67 & 37.21 \\
\hline$-51-60$ & 26.74 & 11.63 & 19.19 \\
\hline$->60$ & 12.79 & 9.30 & 11.05 \\
\hline Mean & 47.12 & 45.70 & 46.41 \\
\hline t-test ( $p$-value) & $0.915^{\mathrm{NS}}(0.362)$ & & \\
\hline \multicolumn{4}{|l|}{ Experience (years) } \\
\hline$<11$ & 15.12 & 23.26 & 19.19 \\
\hline$-\quad 11-20$ & 69.77 & 70.93 & 70.35 \\
\hline$-\quad>20$ & 15.12 & 5.81 & 10.47 \\
\hline Mean & 17.97 & 15.53 & 16.75 \\
\hline t-test ( $p$-value) & 1.662 NS $^{\text {NS }}(0.098)$ & & \\
\hline
\end{tabular}

Remark: NS: non-significant.

Table 2 - Characteristics of Traditional Shop in 2011

\begin{tabular}{|c|c|c|c|}
\hline Item & $\begin{array}{l}\text { Sample Group (\%) } \\
\text { Near }(n=86)\end{array}$ & Away $(n=86)$ & All $(n=172)$ \\
\hline $\begin{array}{l}\text { Start the shop (\%) } \\
\text { - Self } \\
\text { - Parent }\end{array}$ & $\begin{array}{l}66.28 \\
33.72\end{array}$ & $\begin{array}{l}75.58 \\
24.42\end{array}$ & $\begin{array}{l}70.93 \\
29.07\end{array}$ \\
\hline $\begin{array}{l}\text { Shop ages (years) } \\
-<11 \\
-11-20 \\
-21-30 \\
->30 \\
\text { Mean } \\
\text { t-test (p-value) }\end{array}$ & $\begin{array}{l}12.79 \\
45.35 \\
22.09 \\
19.77 \\
20.62 \\
1.963^{\text {NS }}(0.092)\end{array}$ & $\begin{array}{l}26.74 \\
34.88 \\
29.07 \\
9.30 \\
17.90\end{array}$ & $\begin{array}{l}19.77 \\
40.12 \\
25.58 \\
14.53 \\
19.26\end{array}$ \\
\hline $\begin{array}{l}\text { Working hours (hours) } \\
-<12 \\
-12-15 \\
->15 \\
\text { Mean } \\
\text { t-test ( } p \text {-value) }\end{array}$ & $\begin{array}{l}17.44 \\
68.60 \\
13.95 \\
13.17 \\
1.008^{\mathrm{NS}}(0.315)\end{array}$ & $\begin{array}{l}16.28 \\
80.23 \\
3.49 \\
12.90\end{array}$ & $\begin{array}{l}16.86 \\
74.42 \\
8.72 \\
13.04\end{array}$ \\
\hline $\begin{array}{l}\text { Size of the shop }\left(\mathrm{m}^{2}\right) \\
-<26 \\
-26-50 \\
-51-75 \\
-76-100 \\
->100 \\
\text { Mean } \\
\text { t-test ( } p \text {-value) }\end{array}$ & $\begin{array}{l}29.07 \\
43.02 \\
17.44 \\
8.14 \\
2.33 \\
43.73 \\
-1.624^{\text {NS }}(0.117) \\
\end{array}$ & $\begin{array}{l}32.56 \\
46.51 \\
10.47 \\
6.98 \\
3.49 \\
40.95\end{array}$ & $\begin{array}{l}30.81 \\
44.77 \\
13.95 \\
7.56 \\
2.91 \\
42.34\end{array}$ \\
\hline $\begin{array}{l}\text { Hire worker (\%) } \\
\text { - Hire worker } \\
\text { - Not hire worker }\end{array}$ & $\begin{array}{l}25.58 \\
74.42 \\
\end{array}$ & $\begin{array}{l}24.42 \\
75.58\end{array}$ & $\begin{array}{l}25.00 \\
75.00\end{array}$ \\
\hline $\begin{array}{l}\text { Number of worker (worker) } \\
-<3 \\
-3-5 \\
->5 \\
\text { Mean } \\
\text { t-test ( } p \text {-value) }\end{array}$ & $\begin{array}{l}81.40 \\
18.60 \\
0.00 \\
1.92 \\
0.000^{\text {NS }}(1.000) \\
\end{array}$ & $\begin{array}{l}82.56 \\
16.28 \\
1.16 \\
1.92\end{array}$ & $\begin{array}{l}81.98 \\
17.44 \\
0.58 \\
1.92\end{array}$ \\
\hline
\end{tabular}

Remark: NS: non-significant. 
Table 3 shows the daily number of buyers and the percentage of repeated buyer in 2011. The average daily number of buyers is less than 50 buyers. The percentage of repeated buyer in traditional stores is less than 50 percent of the total buyers. The regularly buyer are the buyer who often come to the store to shop. Although there are differences in the number of buyers and the percentage of the regularly buyer, the differences are not significant.

Table 3 - Number of Buyers and Percentage of Repeated Buyer in 2011

\begin{tabular}{|c|c|c|c|}
\hline \multirow{2}{*}{ Item } & \multicolumn{2}{|c|}{ Sample Group (\%) } & \multirow{2}{*}{ All $(n=172)$} \\
\hline & $\operatorname{Near}(n=86)$ & Away $(n=86)$ & \\
\hline \multicolumn{4}{|l|}{ Number of buyer } \\
\hline$-<26$ & 5.81 & 15.12 & 10.47 \\
\hline$-26-50$ & 62.79 & 56.98 & 59.88 \\
\hline$-51-75$ & 13.95 & 18.60 & 16.28 \\
\hline$-76-100$ & 17.44 & 8.14 & 12.79 \\
\hline$->100$ & - & 1.16 & 0.58 \\
\hline Mean & 49.88 & 47.50 & 48.69 \\
\hline t-test ( $p$-value) & $0.790^{\mathrm{NS}}(0.431)$ & & \\
\hline \multicolumn{4}{|l|}{ Regularly buyer (\%) } \\
\hline$-<26$ & 10.47 & 15.12 & 12.79 \\
\hline$-26-50$ & 56.98 & 56.98 & 56.98 \\
\hline$-51-75$ & 27.91 & 24.42 & 26.16 \\
\hline$->75$ & 4.65 & 3.49 & 4.07 \\
\hline Mean & 48.37 & 47.03 & 47.70 \\
\hline t-test ( $p$-value) & $0.496^{\mathrm{NS}}(0.621)$ & & \\
\hline
\end{tabular}

Remark: NS: non-significant.

The Economic Impact of Minimart on Traditional Shop. Table 4 shows the average daily revenue over time and group. It revealed that both groups of the traditional shop experienced declining in revenue. The declining in both groups was statistically significant. The drop in the traditional shop that near the minimart was higher than the drop in the traditional shop that away from minimart. The simple DiD estimation shows that the Impact of the minimart on the traditional shop was $-125,116.28$ IDR. It indicates that the traditional shop near the minimart experienced more loss in revenue as much as 125,116.28 IDR per day. However, the impact was statistically not significant.

Table 4 - Impact of Minimart on Traditional Shop Revenue: Simple Model

\begin{tabular}{llll}
\hline \multirow{2}{*}{ Daily Revenue (IDR) } & Period & $\begin{array}{l}\text { Difference in period } \\
t \text {-test }(p \text {-value) }\end{array}$ \\
\cline { 2 - 4 } Near & After Minimart & Before Minimart & $-316,453.49^{* *}$ \\
\multirow{2}{*}{ Away } & $1,325,813.95^{* *}$ & $1,642,267.44^{* *}$ & $-5.650(0.000)$ \\
& $1,316,162.79^{* *}$ & $1,507,500.00^{* *}$ & $-191,337.21^{* *}$ \\
\hline Difference in group & & & $-5.482(0.000)$ \\
$t$-test $(p$-value) & $9,651.16^{* *}$ & $134,767.44^{* *}$ & $-125,116.28^{\text {NS }}$ \\
\hline
\end{tabular}

Remark: NS: non-significant; **, significant at 1\% level; 1 US $\$=13.500$ IDR.

Table 5 shows both groups has experienced the decline in profit. The table shows that the drop in profit in both groups was statistically significant. The table also shows that the traditional shop that close to minimart experience more lost in Profit. The impact on profit ($25,193.02$ IDR) was statistically significant. The simple model significantly indicates that the traditional shop that are close to minimart experience more loss in profit as much as 25,193.02 Rupiah per day.

Moving into the Econometric Model, Table 6 and Table 7 shows the regression result. Table 6 provides the estimated effect of the minimart on traditional shop revenue while Table 7 provides the estimated effect of the minimart on traditional shop profit. 
Table 5 - Impact of Minimart on Traditional Shop Profit: Simple Model

\begin{tabular}{llll}
\hline \multirow{2}{*}{ Daily Profit (IDR) } & Period & Before Minimart & $\begin{array}{l}\text { Difference in period } \\
t \text {-test }(p \text {-value) }\end{array}$ \\
\cline { 2 - 4 } Near & After Minimart & $193,755.81$ & $-47,533.75^{\star *}$ \\
Away & $146,222.09$ & $-6.317(0.000)$ \\
& $145,384.59$ & $167,725.29$ & $-22,340.70^{\star *}$ \\
\hline Difference in group & & & $-4.490(0.000)$ \\
\hline -test (p-value) & 837.50 & $26,030.52$ & $-25,193.02^{* *}$ \\
\hline
\end{tabular}

Remark: **, significant at $1 \%$ level; 1 US $\$=13.500$ IDR.

Table 6 Impact of Minimart on Traditional Shops Revenue: Econometric model

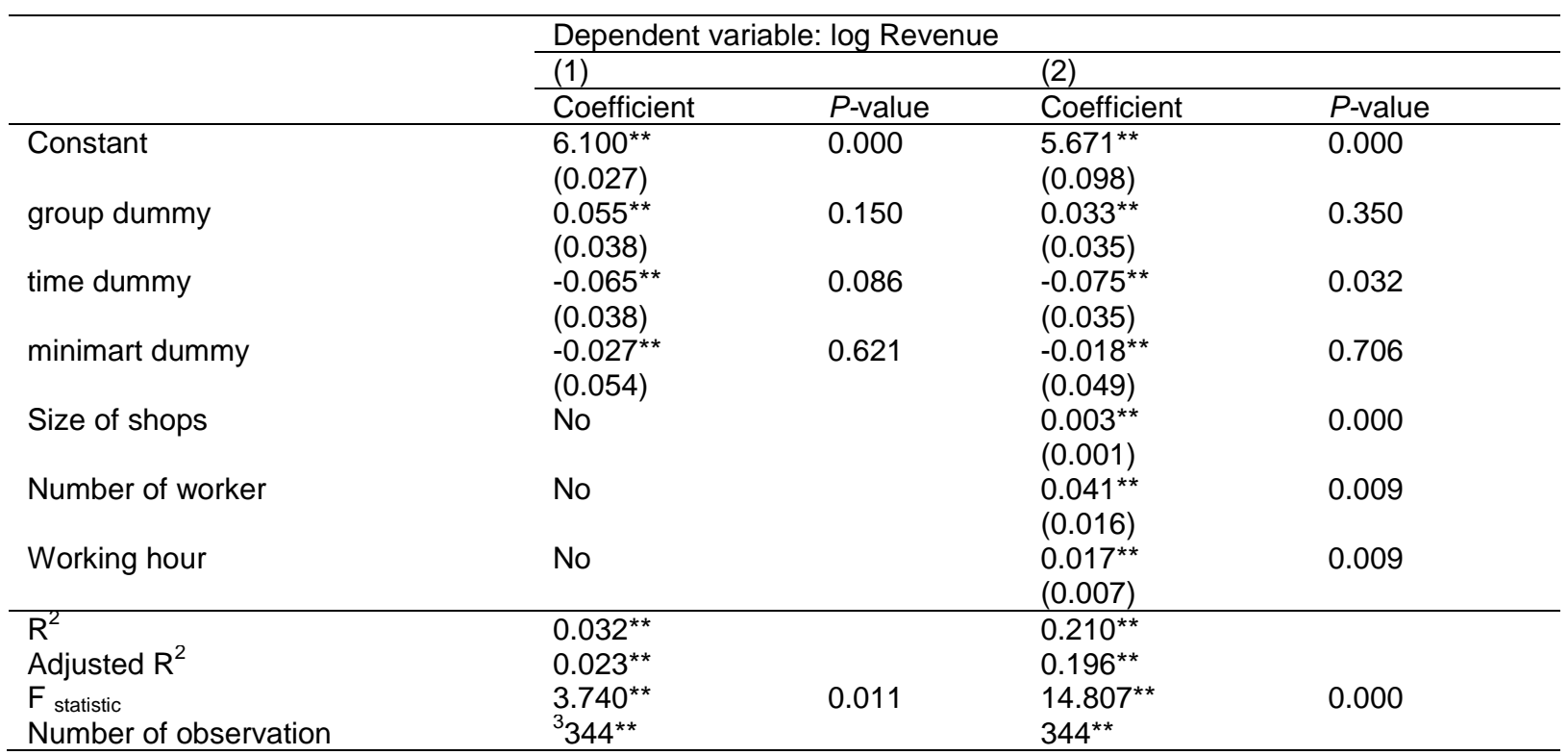

Remark: *, **, significant at $5 \%$ and $1 \%$ level; standard error in parentheses.

The firs column in Table 6 measures the impact of minimart without control variable; the second column measures the impact of minimart with the control variable. The first column shows that the estimated coefficient of minimart is -0.027 . Thus, the minimart gives negative effects as much as $2.7 \%$ on traditional shop revenue. However, the coefficient is not significant. Thus, it can be inferred that the minimart gives no significant impact on the changes in traditional revenue that near to the minimart.

Table 7 shows that both columns are significant at $1 \%$ level of significant. The estimated coefficient of the impact of the minimart in column one is -0.055 . It means the minimart gives negative effects as much as 5.5\% on traditional shop profit. Furthermore, the minimart reduces the traditional shop profit by 5.5\%. However, the coefficient is not significant. Thus, the minimart has no significant impact on the traditional shop profit that closes to the minimart.

Furthermore, column two in Table 5 and Table 6 show that the addition of control variables in the model resulting in an increase in the $\mathrm{R} 2$ value. Adding the control variable also inflict the $F_{\text {statistics }}$ becomes more significant. In contrast to the $F_{\text {statistics, }}$ adding control variables in the model were reducing the coefficient of minimart impact estimators. Thus, the revenue and profit of traditional shop were significantly influenced by the control variable; shop size, the number of workers and working hour.

The declining in revenue and profit were in line with Suryadarma (2007) and Poesoro (2008). The presence of modern stores gives negative impact on the performance of traditional traders; however, the impact is not significant. The results of interviews indicate that there are several causes of declining revenue and profit. That is the declining in the 
number of buyers at the traditional shops. Traders complained they increasingly deserted shop buyers.

Table 7 - Impact of Minimart on Traditional Shops Profit: Econometric model

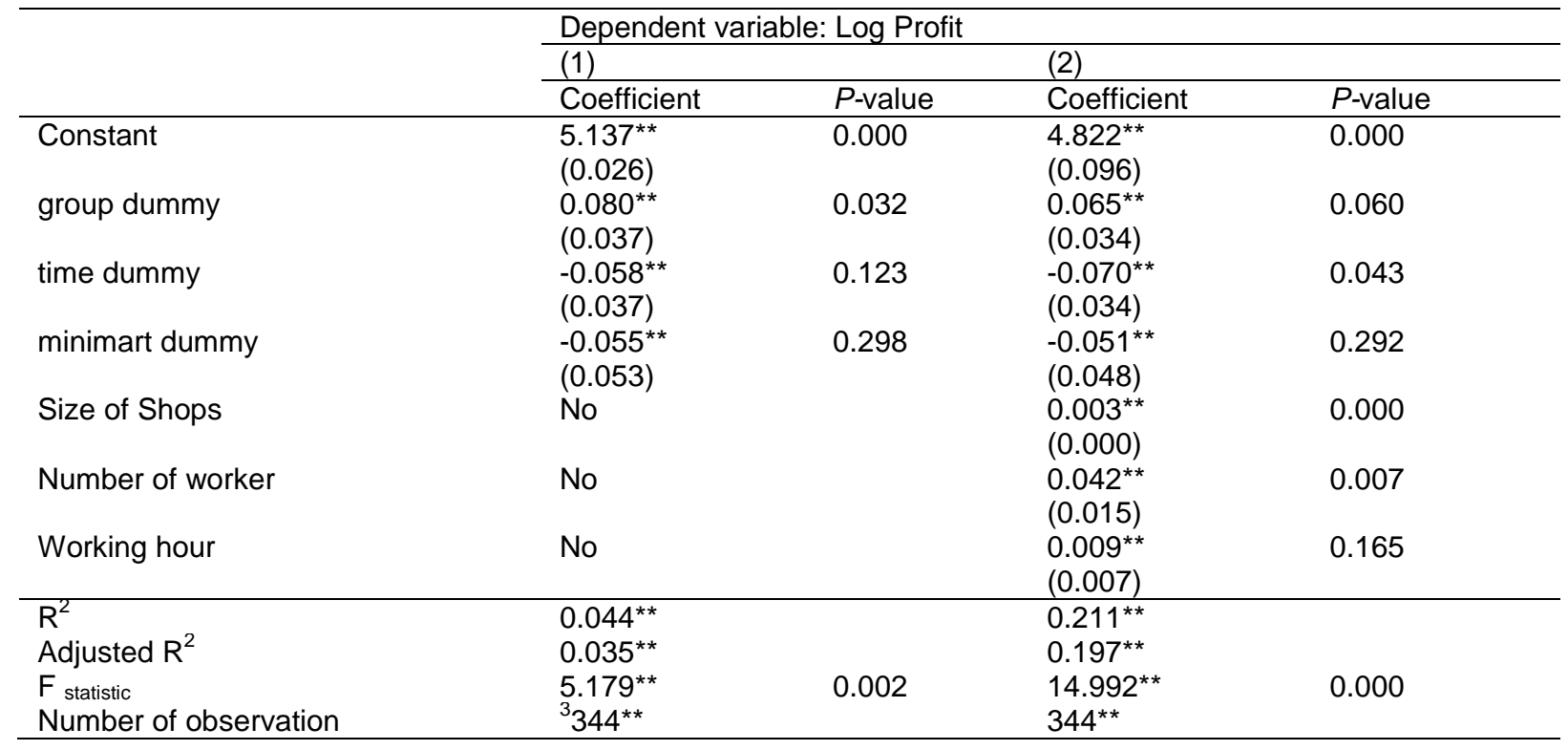

Remark: *, **, significant at $5 \%$ and $1 \%$ level; standard error in parentheses.

The Traditional shop is a business with a small range of coverage area. It is different with minimart. The number of daily buyers at traditional shops is smaller compared to minimart. Most of the buyers of traditional shops are neighbors who live around the shop. The coverage area of the traditional shop is narrower when compared to minimart. Minimart with average area reaches $200 \mathrm{~m}^{2}$ can effectively reach out to a radius of at least $500 \mathrm{~m}$ from the minimart. The size and coverage area of the traditional shop distinguishes the traditional shop and minimart. Traditional shops only have an average area of less than $50 \mathrm{~m}^{2}$. The data shows that less than $50 \%$ of buyers at traditional shops are neighbors who become repeated customers who regularly shop at traditional shops in their neighborhood.

Interviews showed that the traditional shop owners feel the presence of minimart inflict a decrease in the number of buyers. From year to year, the number of buyers has decreased. The traditional shop owner revealed that the factors causing the decline in revenue and profit were the reduction in the number of buyers. Furthermore, the owner of the shop found the cause of a decrease in the number of buyers is happening because of the minimart near their shops. The owner felt that the presence of minimart was inflicting less crowded shop. The decline in the number of buyers that occurs continuously over time was lead to a decrease in revenue and profit.

Table 8 shows that the two groups of traditional shops decreased a significant number of buyers. Before the minimart establishes, the average number of daily buyers were more than 50 buyers. In the shop that in the near minimart group, the number of buyers before the minimart established were more than 60 buyers. After the minimart came, the number of buyers has decreased. Both of the group has decreased. However, the shop near minimart has larger in decline. The table indicates that despite the discrepancy in the decrease in the number of buyers were only five buyers, but the decrease was statistically significant.

The minimart was not directly affecting the revenue and profit, but the direct impact was on the decline in the number of buyers. Even though both groups experienced a reduction in the buyers, the traditional shop near minimart experienced the larger decline. Table 8 shows that despite the difference in the decrease in the number of buyers among the shops that near and away from minimart are only five buyers, the decline was statistically significant. Thus, minimart not directly affects the revenue and profit, but the immediate impact is on the number of buyers. 
Table 8 - Changes in Number of Buyers on Traditional Shop Before and After Minimart

\begin{tabular}{|c|c|c|c|}
\hline \multirow{2}{*}{ Number of Buyer } & \multicolumn{2}{|l|}{ Period } & \multirow{2}{*}{$\begin{array}{l}\text { Changes } \\
t \text {-test ( } p \text {-value) }\end{array}$} \\
\hline & 2011 & 2006 & \\
\hline Near & $49.88^{\star \star}$ & $63.90^{\star *}$ & $\begin{array}{l}-14.02^{\star *} \\
-9.415(0.000)^{\star *}\end{array}$ \\
\hline Away & $47.50^{* *}$ & $56.22^{* *}$ & $\begin{array}{l}-8.72^{* *} \\
-5.789(0.000)^{* *}\end{array}$ \\
\hline $\begin{array}{l}\text { Difference in group } \\
t \text {-test ( } p \text {-value) }\end{array}$ & $\begin{array}{l}2.38^{\star} \\
0.790(0.431)^{\star}\end{array}$ & $\begin{array}{l}7.67^{\star *} \\
2.177(0.031)^{\star *}\end{array}$ & $\begin{array}{l}-5.29^{\star *} \\
-2.498(0.013)^{\star \star *}\end{array}$ \\
\hline
\end{tabular}

Remark: *, **, significant at $5 \%$ and $1 \%$ level; $p$-value in parentheses.

Furthermore, the cause of reduced in the number of the buyer was due to many emerging new "traditional" shop. They emerge with several innovations to attract the attention of buyers. There are several innovations made by the new traditional shops. Based on observations on some of the many new shops popping up, some innovation is carried out as follows: The First formed a partnership with the tobacco companies that cigarette companies beautify the look of the outside and inside of the new shop. Tobacco companies will use the shop as a place of branding cigarette products. The second was the changes in the arrangement of merchandise based on certain categories such as in the minimarts. The goods become tidier and easily selected by the buyer. The third was the implementation of self-service services such as minimart. The self-service makes the buyer can easily choose their items and then pay at the cashier.

The presence of minimart and the new traditional shops have sprung up forcing the old traditional shops to innovate to survive in the increasingly fierce competition. Table 9 shows the strategies carried out by traditional shops in Malang. The strategies that most traditional do is diversify products, better display, and adding new brands. Additionally, lower prices and self-service also choices made by traditional shops to compete with other shops and minimart.

Table 9 - Strategy Undertaken by Traditional Shop

\begin{tabular}{ll}
\hline Strategy & $\%$ \\
\hline Diversify Produce & 44.19 \\
Better Display & 40.12 \\
Add New Brand & 38.37 \\
Reduce Prices & 31.98 \\
Self-Services & 19.77 \\
Discontinue Product & 15.12 \\
Reduce Expense & 12.79 \\
Home Delivery & 6.98 \\
\hline
\end{tabular}

Retail business is a business that is highly dynamic and evolving all the time. In the retail change theory (Fernie, at al, 2003), the development of a new retail format followed the principles established by the wheel, life cycle and conflict theories. To enter and become part of the existing retail business, retailers must consider the environment in their business. Also, the new shop must also consider the retail, price, product range, geographical expansion, and management style. Retailers that have matured in the business would have to deal with the new competitor; innovation is a must to survive. However, to be able to survive and successfully absorbed into existing retail business, the new shop should operate and in a manner that is acceptable and attractive to customers. Innovating, this should be done by the new and old traditional shop to survive in the business.

\section{CONCLUSION}

From the previous discussion, most of the traditional shops in Malang experience depression in the revenue and profit. Both traditional shop near and far from minimart experienced significant loss of revenue and profit. Even though minimart gives a negative 
impact on revenue and profit, but the presence of minimart does not have a major impact on the performance of the traditional shop.

Factor that is suspected to be the cause of performance degradation is the drop in the number of buyers as a result of increasing competition from traditional shops. The number of new traditional shops with a variety of innovations made it more attractive to buyers to shop. Furthermore, further study needs to determine the effect of competition between traditional shops on the performance of the traditional shop itself.

\section{REFERENCES}

1. Abadie, A. (2005), Semiparametric Difference-in-Differences Estimators, Review of Economic Studies, 72, (1), 1-19

2. Binswange, H. P., \& Khandker, S. R. (1993). How infrastructure and financial institutions affect agricultural output and investment in India. Journal of Development Economics , 41, 337-366.

3. Cochran, W. G. (1977). Sampling Technique. New York: John Wiley and Son Inc.

4. Dawson, J. (2010). Retail Trend in Europe. in M. Krafft, \& M. K. Mantrala, Retailing in The 21st Century (page. 63-81). Berlin Heidelberg: Springer.

5. Duflo, E. (2001). Schooling and labor market consequences of school construction in Indonesia: Evidence from an unusual policy experiment. American Economic Review , 91 (4), 795-813.

6. Dyck, J., Woolverton, A. E., \& Rangkuti, F. Y. (2012). Indonesia's Modern Food Retail Sector: Interaction With Changing Food Consumption and Trade Patterns, EIB-97, U.S. Washington: Department of Agriculture, Economic Research Service.

7. Fernie, J., Fernie, S., \& Moore, C. (2003). Principles of retailing. Amsterdam: ButterworthHeinemann.

8. Frankenberg, E., Suriastini, W., \& Thomas, D. (2005). Can expanding access to basic healthcare improve children's health status? Lessons from Indonesia's 'Midwife in the Village' program. Population Studies , 59 (1), 5-19.

9. Galiani, S., Gertler, P., \& Schargrodsky, E. (2005). Water for life: The impact of the privatization of water services on child mortality. Journal of Political Economy , 113 (1), 83-119.

10. ITPS. (2004). The EC regional sctructural funds impact in Sweden 1995-1999: A quantitative analysis. Ostersund: ITPS (Institutet för Tillväxtpolitiska Studier).

11. Jacoby, H. G. (2002). Is There an Intrahousehold 'Flypaper Effect'? Evidence from a School Feeding Programme. The Economic Journal , 112 (476), 196-221.

12. Joseph, M., Soundarajan, N., Gupta, M., \& Sanghamitra, S. (2008). Impact of organized retailing on the unorganized sector. New Delhi: ICRIER.

13. Pitt, M. M., \& Khandker, S. R. (1998). The impact of group-based credit programs on poor households in Bangladesh: Does the gender of participants matter? Journal of Political Economy , 106 (5), 958-998.

14. Poesoro, A. (2008). Dampak Supermarket terhadap Keberadaan Pasar Tradisional di Daerah Perkotaan di Indonesia (Impact of Supermarkets on the existance of Traditional Markets in Urban Areas in Indonesia). Bisnis \& Ekonomi Politik, 9 (2), 71 - 84.

15. Ravallion, M. (2008). Evaluating Anti-Poverty Programs. In T. P. Schultz, \& S. Straus, Handbook of Development Economics (pp. 3787-3846). Amsteradam: Elsevier B.V.

16. Ravallion, M., van de Walle, D., \& Gautam, M. (1995). Testing a social safety net. Journal of Public Economics , 57 (2), 175-199.

17. Reardon, T., Timmer, P., Rozelle, P., Hu, D., \& Wang, H. (2004). The Emergance of Supermarket with Chinese Characteristics: Challenges and Opportunities for China's Agriculture Development. Development Policy Review , 557-586.

18. Suryadarma, D., et al., (2009). Traditional food traders in developing countries and competition from supermarket: Evidance from Indonesia. Food Policy , 35, 79-86.

19. Suryadarma, D., et al., (2007). Impact of Supermarket on Traditional Markets and Retailers in Indonesia's Urban Centers. Jakarta: Semeru Research Institute. 
20. Thomas, D., et al., (2003). Iron deficiency and the well-being of older adults: Early results from a randomized nutrition intervention. Minneapolis: Paper Presented at the Population Association of America Annual Meetings.

21. Traill, W. B. (2006). The Rapid Rise of Supermarket. Development Policy Review , 163174.

22. van de Walle, D. (2004). Testing Vietnam's safety net. Journal of Comparative Economics , 32 (4), 661-679.

23. Weitz, B. A., \& Whitfield, M. B. (2010). Trend in U.S. Retailing. In M. Krafft, \& M. K. Mantrala, Retailing in The 21st Century. 83-99. Berlin Heidelberg: Springer. 